\title{
岐阜県製品技術研究所 研究開発部
}

山下 典 男*

\section{1. 製品技術研究所}

岐皁県は，豊かな自然と良好な立地条件を背景に，県内 各地において培われた伝統的文化・技術を核として，県内 7 大産業(繊維, 陶磁器, 紙, 金属刃物，木工，プラスチッ ク，食品）が発達してきた.

これら地場産業を支援する機関として，明治 42 年に岐 阜地域に岐阜県工業試験場が設立された。その後, 昭和 47 年に岐皁県工業技術センターに名称を変更し, 昭和 52 年 にその一部門の瀻維部門が瀻維試験場として，平成 6 年に 食品部門が食品加工ハイテクセンターとして独立した．プ ラスチック業界に関する対応は，主に工業技術センターで 行ってきた。

他の地場産業についても，紙関連は紙業試験場（昭和 3 年に製紙試験場として設立, 昭和 49 年改称), 金属刃物関 連は金属試験場（昭和 12 年設立）, 陶磁器関連は陶磁器試 験場（明治 44 年設立)，木工関倸は工芸試験場（昭和 12 年設立）がそれぞれ設置され，試験研究指導を行ってきた。

しかし, 時代の変遷とともに,「研究開発立県」を目指 す岐阜県では, 低迷する地域産業の活性化, 新産業の創出 · 育成など新時代への対応を図るため, 平成 8 年科学技術振 興センターを設立し，その金下に従来の縦割りに配置して いた工業系・農林業系, 衛生系等 18 の試験研究機関を一 元化し, ネットワーク連携型の研究体制として再編整備し た。その一環として，平成 11 年 4 月に工業技術センター, 繊維試験場，食品加工ハイテクセンター，紙業試験場，金 属試験場の 5 機関が一つに統合・再編され，新たに岐阜県 製品技術研究所として発足した。

現在，管理課，研究開発部，技術支援部，美濃分室，関 分室打よび食品加工ハイテクセンターの 1 課 2 部 3 分室体 制で所長以下全職員 59 名で, うち研究職員 41 名で構成さ れている.

\section{2. 研究開発部}

研究開発部は, 県が推進するネットワーク連携型研究体 制の一環として, 工業技術センター新素材利用技術部，繊 維試験場試験研究部の研究開発部門が統合する形で再編さ

\footnotetext{
* Yamashita, Norio

岐阜県製品技術研究所 研究開発部

岐阜県羽島郡笠松町北及 47 ( \% 501-6064)

2004.5.15 受理
}

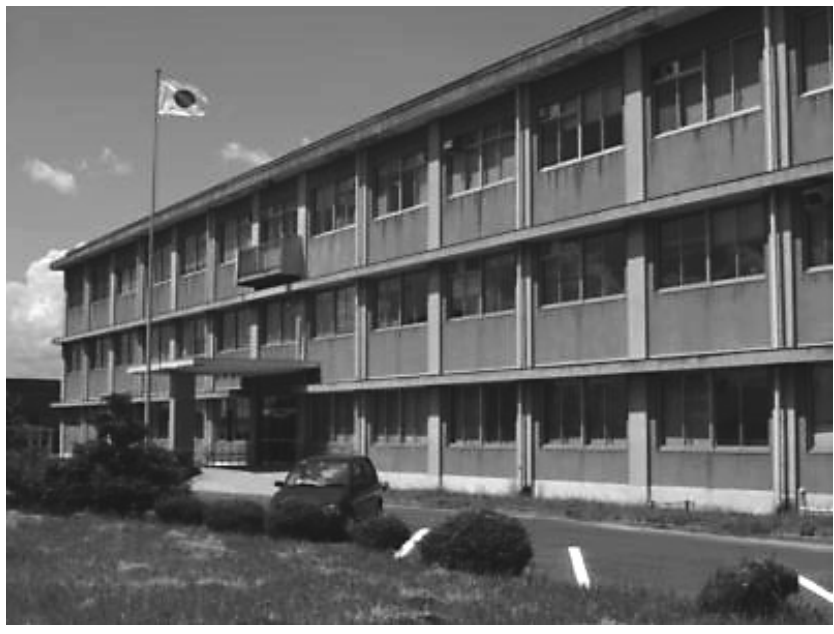

図 1 岐阜県製品技術研究所外観

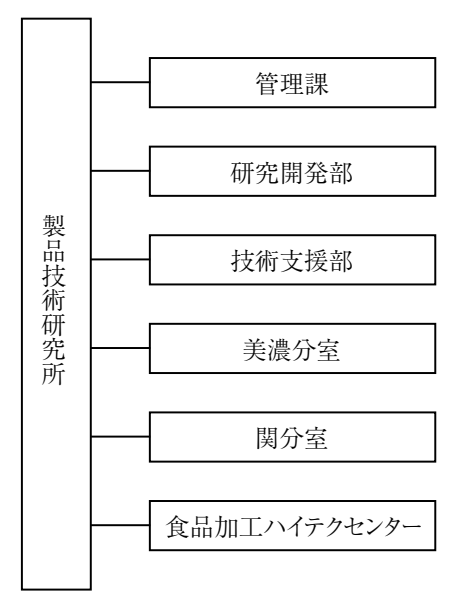

図 2 岐阜県製品技術研究所組織図

れ, 発足した. 現在, スタッフは部長以下 9 名で, 主に化 学工業, プラスチック, 石灰, 繊維を中心とし, 新素材 · 新製品・新プロセス等の重点化した研究開発を行っている. また技術支援部と連携して，質の高い技術支援と研究の実 用化を目指している.

従来から比べると研究内容も業種対応型から融合型と なってきて㧍り，産学官連携を軸とした体制で研究に取り 組んでいる.

近年の研究では，化学，プラスチック，石灰関連で，無 機系ナノ材料とナノ分散技術による「ポリマーナノコンポ 
ジットの製造技術研究」を業種を超えた形で実施している. 纎維関連では, 平成 13 年度補正地域新生コンソーシアム 研究開発事業において産学官共同研究「サンプル・超小 ロット知的縫製システムの開発研究」を実施し, 国内型の アパレルの新しい生産システムを提案した。 また不織布分 野では，新しい市場を模索する「住設資材などの生活空間 資材への応用研究」,「環境に優しい繊維型複合材料に関す る研究」等を実施している，石灰関連では，「石灰の環境 適合機能材料への活用」を産学官共同研究により実施して いる.

\section{3. 研究開発概要}

\section{1 成形加工分野に関する研究の歴史}

旧工業試験場, 工業技術センター時代においては, 研究 開発は業種対応型であり，プラスチック成形加工に関する 研究が中心となっていた. 昭和 30 年代後半から 40 年代前 半の高度成長期には, 技術革新や大量生産が進展してきた ことから, 関連試験設備の設置や業界指導事業が充実し, 研究も本格的に行われた。

当時のプラスチックに関する研究は化学部が担当し, 材 料開発から成形加工技術に関するテーマまで幅広く行われ たが，主に品質管理，製品品質の向上に関するものが中心 となっていた. 以下研究例を挙げると, 材料開発に関する 研究としては, 難燃剤を添加したプラスチック材料やフィ ラー強化プラスチック材料の試作開発等があり, 成形加工 技術については，金型温度分布の測定等を行い，温度分布 と成形条件との関係を解明するなど, 品質管理に重点を置 いた研究を行った.

また，新材料に関する成形加工については「ファインセ ラミックスの射出成形技術研究」があり, アルミナ・ジル コニアの射出成形法による製造プロセスでの各工程におけ る要因の影響について研究を行った. 金型関係では, 加工 容易な材質を使用することで, 多品種少量生産用の簡易金 型の研究も行った.

\section{2 ポリマーナノコンポジット材料の開発}

工業技術センター新素材利用技術部を経て，製品技術研 究所研究開発部となってからは, 新技術新素材開発に研究 の重点が移り, 平成 12 年度〜平成 15 年度に「ポリマーコ ンポジットの製造技術研究」を行った. 当研究は, 産学官 連携のプロジェクト研究として実施し，プラスチック関連 企業で利用が期待できる新規材料の開発を目的としてい $ろ^{1) \sim 4)}$.

内容は機能，形態を制御したナノ材料を開発し，ポリ マー・ポリマー間の相構造, ナノ均一分散制御技術を研究 し, 新規で高性能, 高機能を有する複合プラスチック材料 を開発，新製品へ応用を図るものである.

プラスチックに無機系のナノ微粒子を均一に分散させる ことができれば，機械的物性の格段の向上の他, 耐熱性や 透明性の確保, ガスバリアー性の向上など通常のフィラー コンポジットとは全く異なる性質のプラスチックを得るこ とができる.

ナノコンポジットの多くの研究は, モンモリロナイトな ど天然に存在するスメクタイト系粘土鉱物の材料を中心と して進められているが, 本研究では水熱合成により安価に

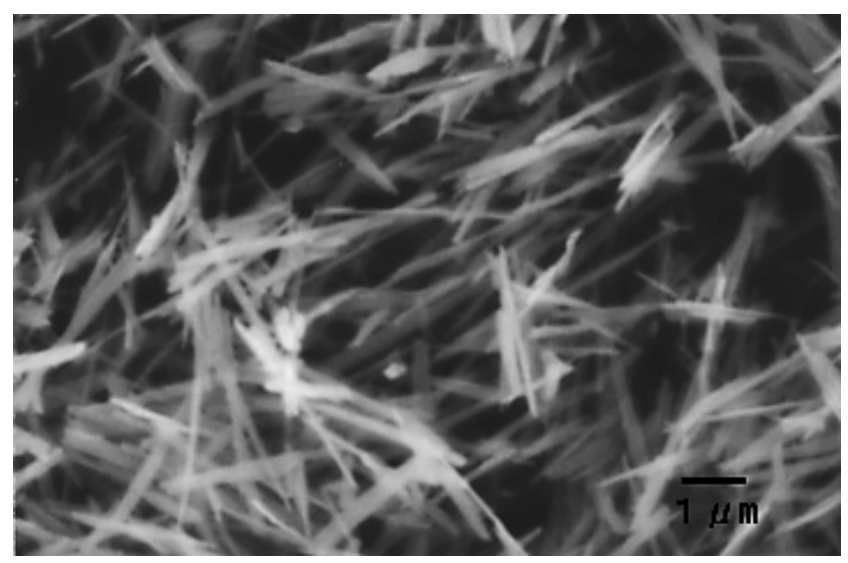

図 3 開発した針状ベーマイト

合成できるべーマイト $(\mathrm{AlO}(\mathrm{OH}))$ に着目した。

ベーマイトはアルミナの水和物で酸，アルカリ，有機溶 媒に対し安定である. しかし, 電子密度が高く, 有機物を インターカレートしにくいため, 層間剥離をさせることが きわめて困難である。 そこで，水酸化アルミニウムを特殊 な溶媒の存在下において, エチレングリコール等のジオー ル類や縮合エチレングリコール類，アミノアルコール類を 作用させ，ベーマイトを平板状のナノ微粒子に形態制御し， ベーマイトの層間にこれらをインターカレートしたベーマ イトを得た。さらに，このベーマイトを化学的に層間剥離 させることにより, ナノコンポジット材料として応用可能 な「ナノサイズ層間剥離板状ベーマイト」を開発した。

これらを樹脂に分散させることにより，プラスチック製 品の機械的強度はもちろん難燃性, ガスバリア性, 透明性 などの機能を大幅に向上させることが期待できる. 当研究 の成果である下記各種ベーマイトは, 県内共同研究企業と 特許を共同出願し, 現在事業化への展開を模索している.

(1) 針状ベーマイト（特願 99-041357, 特願 01-240633）

- 特徴：針状, 高アスペクト比 $(30 \sim 50)$, 高配向性,

熱的・化学的に安定, 針長が長い $(3 \sim 8 \mu \mathrm{m})$

·用途：難燃剂（プラスチック用，ドリップ抑制用), 補強剤（プラスチック，七ラミック用）, 高アスペク ト比アルミナ原料

(2) 板状ベーマイト（特許 02-261425）

- 特徵: 板状, 微細 $(0.8 \sim 6 \mu \mathrm{m})$, 高配向性, 面内等 方向性, 熱的 - 化学的に安定

・用途：難燃剤 (プラスチック用), 補強剤 (プラスチッ ク，七ラミック用), 光輝剤 (塗料, 顔料, 化粧品用), 高アスペクト比アルミナ原料

(3) ナノサイズ層間剥離板状ベーマイト（特願 03-071085） ・特徵：層間剥離したベーマイト，ナノサイズ，極薄板 状 (平均 $50 \mathrm{~nm}$ )

・用途：ナノコンポジット用板状フィラー, ガスバリア 性，透明性，難燃性

(4) UVカットスピネル被覆板状ベーマイト（特願 03153766)

・特徵：板状ベーマイトにスピネル被覆, 紫外線反射 吸収

・用途：化粧品（ファンデーション）プラスチック用紫 外線防止剂 


\section{3 今後の研究について}

平成 16 年度は新技術, 新素材開発型の研究だけでなく, 地域密着型の研究も重要視し,「機能性プラスチック材料 の開発研究」,「新素材に関する加工技術研究」の 2 テーマ がスタートする.

前者は，これまで蓄積してきたコンポジットに関する研 究や技術をべースにして, 将来的に必要な或いは重要とな る新しい材料や技術を開発し, 新製品開発や新産業創出に 貢献することを目的としている。一方, 後者は地域密着型 テーマとして，プラスチック材料の中でも開発が盛んに行 われている新材料を利用して製品化（例えば射出成形によ る製品化）を行う場合に必要となる基本的データやフィ ラー添加による効果について研究し, 製品化における技術 的支援を行うことを目的としている。

これらの研究により，プラスチックを含む関連産業の先 端技術と基盤技術の研究開発を行い，地域産業の発展に貢 献していきたいと考えている.

\section{4. 開放試験室設備}

製品技術研究所では，研究開発とともに地域産業に対す る質の高い技術支援を行うため, 関連の試験研究機器を設 置している.その中で，企業に活用していただくために設 置した開放試験室設備がある.

主にプラスチック業界で利用されている開放試験室とし て,「新素材融合化開放試験室」(平成元年設置),「複合材 料開発支援共同研究室」(平成 3 年設置),「レオロジー研究 室」(平成 3 年設置) があり，設備を開放している．設置さ れている主な装置は次のと打りである.

(1) 定性分析関係設備

・EPMA（電子線マイクロアナライザー）

· NMR（核磁気共鳴測定装置）

·微小高温 X 線回折装置

- ESCA（X 線光電子分光分析装置）

(2) 成形加工特性測定関係設備

·熱分析測定装置（TG-DTA，TMC，DTA）

-動的粘弾性測定装置

- 混練性測定装置

・熱溶融測定装置（キャピログラフ）

(3) その他

・偏光顕微鏡

・酸素イオン輸率測定装置

・テーバー式摩耗試験器

その他支援事業として, 電話, 来所等による技術相談, 情報提供や現地で行う実地指導, 外部講師を招いての講演 会，技術研修などがあり，随時実施している.

また，企業から依頼を受けた研究内容について研究を実

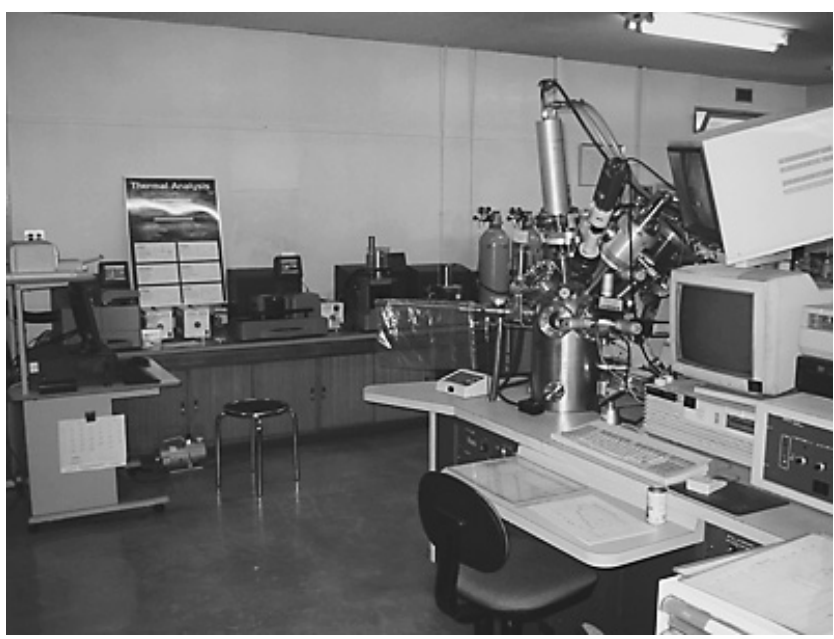

図 4 複合材料開発支援研究室

施する受託研究制度があり, 当研究所の研究成果やこれま でに蓄積している独自技術を活用し，企業の研究開発や製 品化を支援している.

業界支援の一つとして，県内プラスチック組合を中心に 業界が一体となって進めている射出成形に関する技能検定 があり，人材育成の一環として全面的な支援を行っている.

\section{5.おわりに}

回復の兆しが見えてきたとはいえ長引く不況や安価な海 外製品との競争など，最近の企業を取り巻く環境は極めて 厳しい状況にある。これを打破するためには，他の追従を 許さないような地域産業の技術力の飛躍的な高度化㧍よび, 新産業の創出とともに, 産業の情報化を一層推進すること が必要であると考えられる.

今回，プラスチックに関する研究や事業内容の一部を中 心に紹介したが，当研究所では，今後ますます地域産業の 発展に寄与するために, 研究開発においては新しい時代に 向けた新材料や新技術開発に積極的に取り組み, 一方, 企業 との連携をさらに深めていくよう努力したいと考えている. (ホームページ：http：//www.cc.rd.pref.gifu.jp/iri/)

\section{参 考 文 献}

1) 藤吉，道家，鈴木：岐阜県製品技術研究所研究報告, 4, 9 (2003)

2 ) 鈴木, 藤吉, 道家: 岐阜県製品技術研究所研究報告, 4, 17 (2003)

3 ) 藤吉, 道家, 鈴木: 岐阜県製品技術研究所研究報告, 4, 22 (2003)

4 ) 藤吉, 石田, 竹内：Journal of the Society of Inorganic Materials, Japan, 8，204 (2001) 